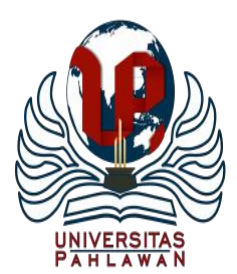

Jurnal Abdidas Volume 2 Nomor 4 Tahun 2021 Halaman 916-921

JURNAL ABDIDAS

http://abdidas.org/index.php/abdidas

\title{
Pelatihan Pemanfaatan Web Enhanced Course dan Collaborative Learning sebagai Penunjang Pembelajaran
}

\author{
Yudha Popiyanto $^{1 \varpi}$, Savitri Suryandari ${ }^{2}$, Anna Roosyanti ${ }^{3}$ \\ Pendidikan Guru Sekolah Dasar, Universitas Wijaya Kusuma Surabaya, Indonesia ${ }^{1,2,3}$

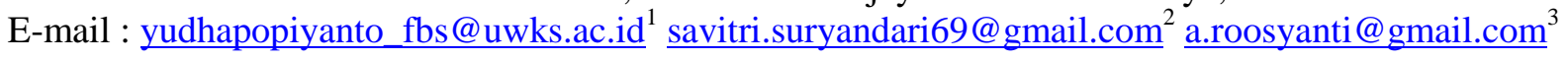

\begin{abstract}
Abstrak
Proses pembelajaran dalam tatanan kehidupan normal baru yang seiring dengan berkembangnya teknologi informasi dan komunikasi menjadi pertimbangan dalam pemilihan topik kegiatan Pengabdian kepada Masyarakat "Pelatihan Pemanfaatan Web Enhanced Course dan Collaborative Learning sebagai Penunjang Pembelajaran di SDN Gili Timur 2 Kabupaten Bangkalan" ini. Kegiatan ini bertujuan untuk memberikan informasi media dan model pembelajaran yang dapat dilaksanakan dalam tatanan kehidupan normal baru. Metode pelaksanaan kegiatan ini dalam bentuk penyampaian materi dan pelatihan yang dilaksanakan secara Dalam Jaringan (Daring) menggunakan Zoom. Dari hasil pelaksanaan kegiatan ini dapat diketahui bahwa minat para guru dan karyawan SDN Gili Timur 2 Bangkalan meningkat untuk dapat memanfaatkan Web Enhanced Course dan Collaborative Learning sebagai penunjang pembelajaran di SDN Gili Timur 2 Bangkalan. Motivasi guru dan karyawan dalam melaksanakan pembelajaran daring semakin juga semakin meningkat setelah dilaksanakan sharing mengenai kendala-kendala yang dihadapi oleh guru, sekolah, siswa, dan orang tua selama pembelajaran daring. Target luaran dari pelaksanaan kegiatan ini berupa artikel yang dipublikasikan di Jurnal ilmiah.
\end{abstract}

Kata kunci: web enhanced course, pembelajaran kolaboratif, pembelajaran daring

\section{Abstract}

The learning process in the new normal order of life which is in line with the development of information and communication technology is a consideration in choosing the topic of this community service activity "Training on the Utilization of Web Enhanced Course and Collaborative Learning as Learning Support at SDN Gili Timur 2 Bangkalan Regency". This activity aims to provide media information and learning models that can be implemented in the new normal order of life. The method of implementing this activity is in the form of delivering material and training which is carried out online using Zoom. From the results of this activity, it can be seen that the interest of teachers and employees of SDN Gili Timur 2 Bangkalan has increased to be able to take advantage of the Web Enhanced Course and Collaborative Learning as learning support at SDN Gili Timur 2 Bangkalan. The motivation of teachers and employees in carrying out online learning is also increasing after sharing about the obstacles faced by teachers, schools, students, and parents during online learning. The output target of this activity is in the form of articles published in scientific journals.

Keywords: web enhanced course, collaborative learning, school from home

Copyright (c) 2021 YudhaPopiyanto, Savitri Suryandari, Anna Roosyanti

$\triangle$ Corresponding author

Address : Universitas Wijaya Kusuma Surabaya

Email:yudhapopiyanto_fbs@uwks.ac.id

DOI : https://doi.org/10.31004/abdidas.v2i4.387

ISSN 2721- 9224 (Media Cetak)

ISSN 2721- 9216 (Media Online) 
917 Pelatihan Pemanfaatan Web Enhanced Course dan Collaborative Learning sebagai Penunjang Pembelajaran -Yudha Popiyanto, Savitri Suryandari, Anna Roosyanti

DOI: https://doi.org/10.31004/abdidas.v2i4.387

\section{PENDAHULUAN}

Covid-19 seketika menjadi perhatian dunia, hampir 200 negara terjangkit oleh Virus ini termasuk Indonesia. Pada tanggal 11 Maret 2020, WHO telah menetapkan Covid-19 sebagai pandemi (WHO, 2020). Peningkatan jumlah kasus positif Covid-19 dialami oleh hampir seluruh Negara. Terhitung per Januari 2021 terdapat lebih dari 1,1 juta kasus di Indonesia, termasuk di dalamnya beberapa kabupaten dan kota di Jawa Timur yang telah menyumbang peningkatan kasus Covid-19 (Dinas Kesehatan Jawa Timur (2020) dalam (Basuki, H.O, 2021). Salah satunya Kabupaten Bangkalan yang beberapa waktu lalu ditetapkan sebagai zona merah

Berbagai upaya penekanan lonjakan kasus Covid-19 telah dilakukan oleh pemerintah, salah satunya melalui kebijakan pembelajaran secara daring (school from home). Kebijakan ini telah berjalan selama setahun lebih, dengan segala tantangan didalamnya. Keadaan ini memacu kita untuk terus mengembangkan proses pembelajaran. Meski kita semua sependapat bahwa dengan atau tanpa adanya pandemi Covid-19 ini, perubahan dalam bidang pendidikan akan terus berlangsung.

Perkembangan Teknologi Informasi dan Komunikasi (TIK) yang sangat pesat di saat terjadinya pandemi Covid-19 ini yang mewajibkan proses pembelajaran dilaksanakan di rumah (school from home), sangat memungkinkan untuk dilaksanakannya pembelajaran secara kolaboratif (collaborative learning).

Collaborative learning dapat berlangsung apabila guru dan siswa bekerjasama menciptakan pengetahuan. Collaborative learning bukan hanya sekedar bekerjasama dalam suatu kelompok, tetapi lebih kepada suatu proses pembelajaran yang melibatkan proses komunikasi secara utuh dan adil. Collaborative learning meliputi kemampuan sosial dan pembelajaran, yang menggabungkan 3 konsep yaitu tanggung jawab individu (individual accountability), keuntungan kelompok (group benefit), dan pencapaian kesuksesan yang sama (equal achievement of success). Tujuan dari collaborative learning adalah meningkatkan interaksi siswa dalam memahami suatu tugas serta siswa mampu mengeksplorasikan apa saja yang ada dalam pikirannya.

Langkah-langkah dalam penerapan collaborative learning menurut Barkley, Cross dan Major terdiri dari lima langkah, yaitu a) mengorientasikan siswa; b) membentuk kelompok belajar; c) menyusun tugas pembelajaran; d) memfasilitasi kolaborasi siswa; dan e) memberi nilai dan mengevaluasi pembelajaran kolaboratif yang telah dilaksanakan. Collaborative learning mengacu pada metode pengajaran di mana siswa dalam satu kelompok yang bervariasi tingkat kecakapannya, bekerjasama dalam kelompok kecil yang mengarah pada tujuan bersama.

\footnotetext{
"Web enhanced course adalah pemanfaatan internet untuk menunjang peningkatan kualitas kegiatan pembelajaran di kelas, sehingga pembelajaran utamanya tatap muka di kelas" (Sa`ud, 2010).

Pendidikan formal dalam jenjang Sekolah Dasar idealnya memanfaatkan web enhanced course dan collaborative learning dalam pembelajaran. Web enhanced course sebagai media pembelajaran melalui fasilitas electronic mail (e-mail), mailing list (milis), file transfer
} 
918 Pelatihan Pemanfaatan Web Enhanced Course dan Collaborative Learning sebagai Penunjang Pembelajaran -Yudha Popiyanto, Savitri Suryandari, Anna Roosyanti

DOI: https://doi.org/10.31004/abdidas.v2i4.387

protocol (ftp), new groups, dan world wide web $(w w w)$. Web enhanced course dapat dikategorikan sebagi sumber belajar by utilization, yaitu sumbersumber belajar dalam proses pembelajaran.

Kompetensi Sumber Daya Manusia abad 21 diantaranya meliputi kemampuan komunikasi dan kolaborasi sekaligus penguasaan teknologi digital, merupakan implikasi dari globalisasi dan perkembangan IPTEK (Hamidy, A \& Purboningsih, 2016). Proses pembelajaran abad 21 tidak lagi dipandang hanya sebagai proses transfer pengetahuan, melainkan sebuah proses komunikasi dan interaksi sosial antar sesama peserta didik dalam membangun pengetahuannya.

SDN Gili Timur 2 merupakan UPTD yang berada dalam naungan Dinas Pendidikan Kabupaten Bangkalan, Propinsi Jawa Timur. Adapun tujuan dari Kegiatan Pengabdian kepada Masyarakat ini adalah memberikan pelatihan kepada peserta yang dalam hal ini guru dan karyawan SDN Gili Timur 2 Bangkalan dalam pemanfaatan web enhanced course dan collaborative learning sebagai penunjang pembelajaran di SDN Gili Timur 2 Bangkalan.

\section{METODE}

Pelaksanaan Kegiatan Pengabdian kepada Masyarakat dilaksanakan pada tanggal 25, 27, dan 28 Mei 2021. Metode yang digunakan melalui kegiatan pelatihan pemanfaatan web enhanced course dan collaborative learning sebagai penunjang pembelajaran di SDN Gili Timur 2 Bangkalan, yang dilaksanakan via Dalam Jaringan (Daring) menggunakan aplikasi Zoom.
Peserta dalam kegiatan ini berjumlah 11 orang yang terdiri dari Kepala Sekolah, 10 orang guru dan 1 orang karyawan SDN Gili Timur 2 Bangkalan. Para peserta dilatih dalam pemanfaatan web enhanced course, selain itu terdapat diskusi mengenai collaborative learning dan dampak psikologis pembelajaran daring bagi siswa, guru, dan orang tua.

Adapun tahapan kegiatannya adalah sebagai berikut:

1. Tahap Perencanaan: melakukan wawancara dengan Kepala Sekolah SDN Gili Timur 2 Bangkalan mengenai kendalakendala yang dihadapi selama pandemi Covid-19, dan proses pembelajaran daring yang telah dilaksanakan oleh sekolah, serta membuat kesepakatan mengenai waktu pelaksanaan kegiatan Pengabdian kepada Masyarakat. Selanjutnya menyiapkan materi pelatihan, serta aplikasi yang diperlukan, misalnya Zoom, Google Form, dan tak lupa menyediakan dana pengganti pulsa kuota internet bagi peserta.

\section{Tahap Pelaksanaan Kegiatan:} melaksanakan pelatihan secara daring melalui Zoom Meeting.

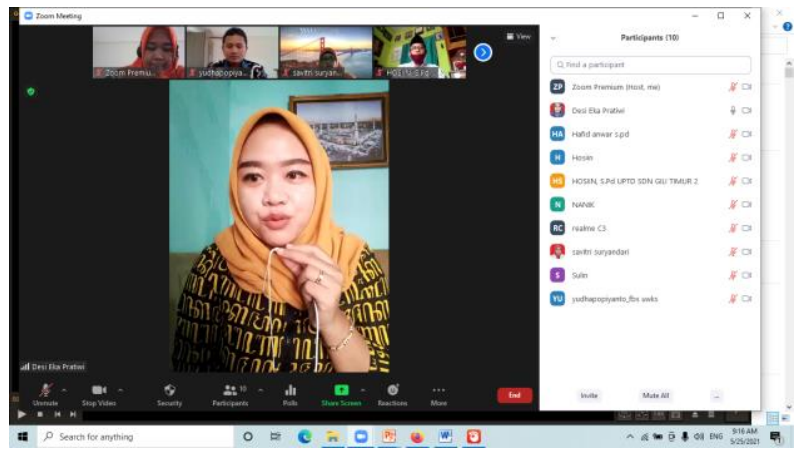

Gambar 1. Sambutan oleh Ketua Program Studi PGSD Universitas Wijaya Kusuma Surabaya 
919 Pelatihan Pemanfaatan Web Enhanced Course dan Collaborative Learning sebagai Penunjang Pembelajaran -Yudha Popiyanto, Savitri Suryandari, Anna Roosyanti

DOI: https://doi.org/10.31004/abdidas.v2i4.387

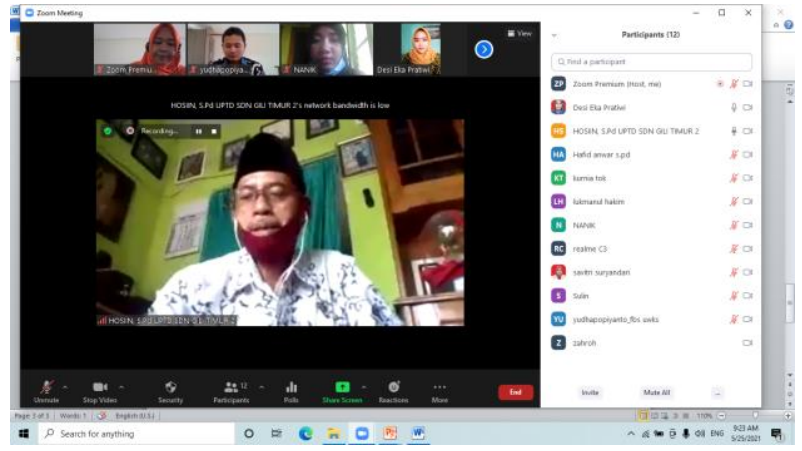

Gambar 2. Sambutan oleh Kepala Sekolah SDN Gili Timur 2 Bangkalan.

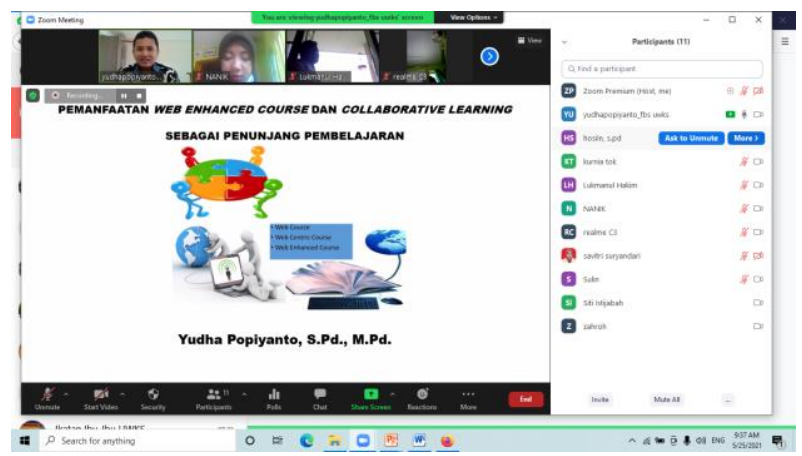

Gambar 3. Penyampaian Materi oleh Narasumber.

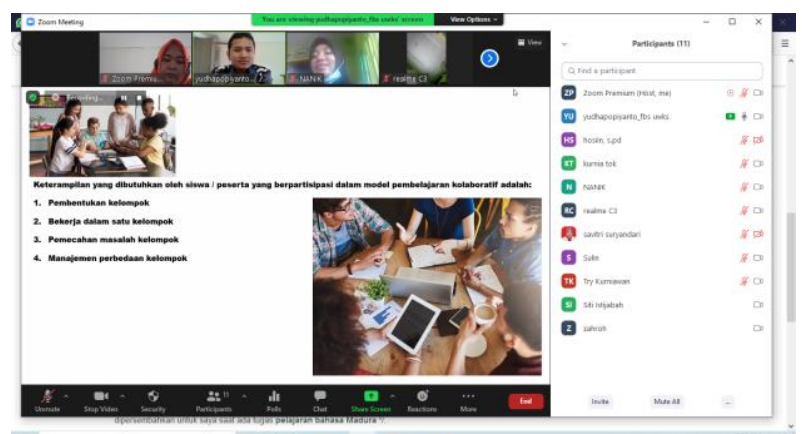

Gambar 4. Penyampaian Materi oleh Narasumber.

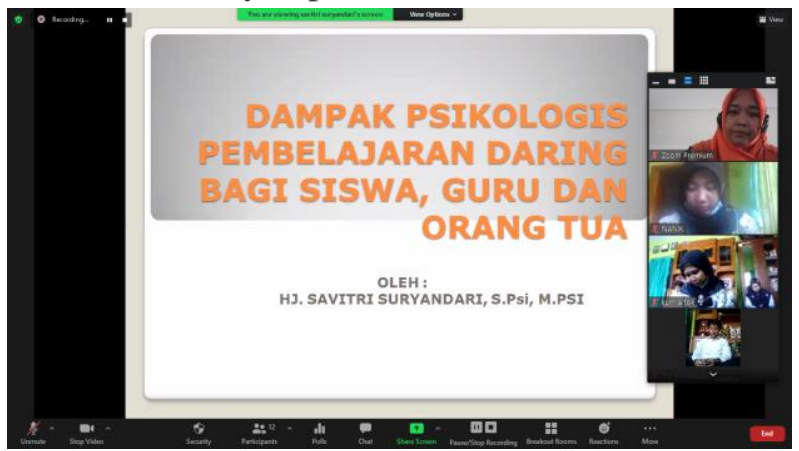

Gambar 5. Penyampaian Materi oleh Narasumber.

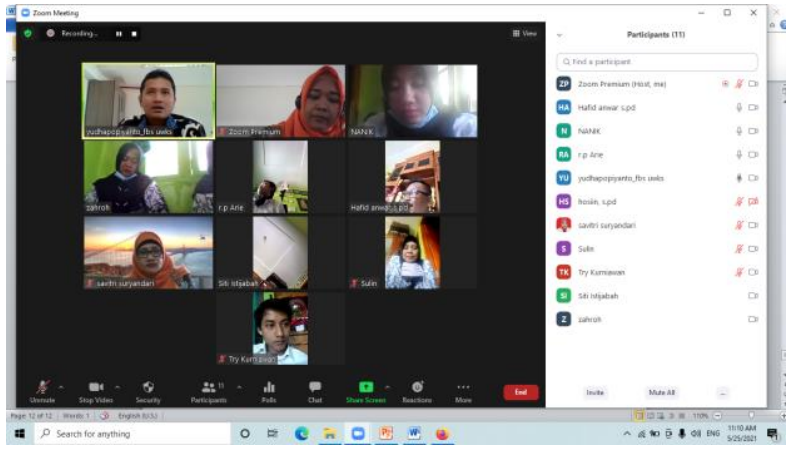

Gambar 6. Sesi Tanya Jawab oleh Peserta.

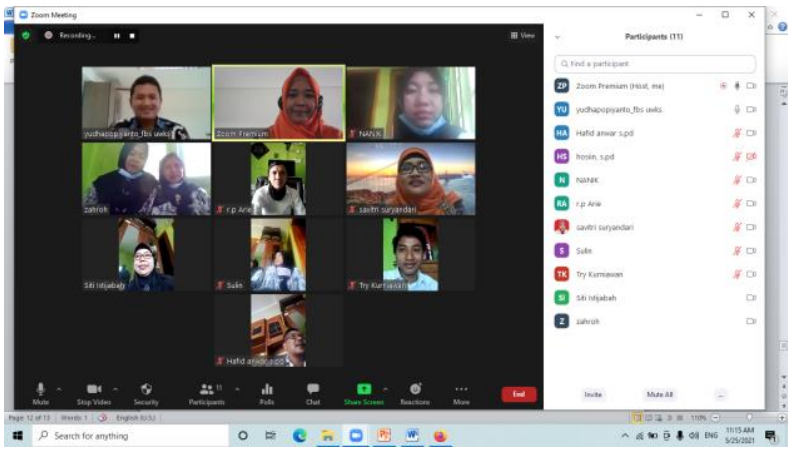

Gambar 7. Sesi Foto Bersama

\section{HASIL DAN PEMBAHASAN}

Kegiatan pengabdian kepada masyarakat ini memberikan dampak yang sangat positif bagi para peserta yakni guru dan karyawan SDN Gili Timur 2 Bangkalan. Para peserta dapat memanfaatkan web enhanced course dan collaborative learning sebagai penunjang pembelajaran di SDN Gili Timur 2 Bangkalan. Antusiasme para peserta sangat tinggi untuk memanfaatkan web enhanced course dalam membantu pembuatan soal-soal untuk latihan maupun ujian, serta untuk penyebaran angket mengenai kepuasan pembelajaran daring. Pemberian tugas dan bahan bacaan bagi siswa juga dapat diberikan melalui website. Web enhanced course dapat menjadi alternatif belajar secara online (Asyhari, A., \& Diani, 2017). 
920 Pelatihan Pemanfaatan Web Enhanced Course dan Collaborative Learning sebagai Penunjang Pembelajaran -Yudha Popiyanto, Savitri Suryandari, Anna Roosyanti

DOI: https://doi.org/10.31004/abdidas.v2i4.387

Motivasi guru dan karyawan dalam melaksanakan pembelajaran daring semakin meningkat setelah dilaksanakan sharing mengenai kendala-kendala yang dihadapi oleh guru, sekolah, siswa, dan orang tua selama pembelajaran daring. Beberapa permasalahan yang menjadi topik diskusi antara lain: motivasi siswa yang rendah selama pembelajaran daring yang disebabkan oleh berbagai faktor; penerapan kurikulum K13 yang kurang maksimal selama pembelajaran daring; solusi menciptakan atmosfer yang baik dan menyenangkan bagi siswa untuk belajar baik di sekolah maupun di rumah; sarana dan prasarana yang masih kurang tersedia dengan baik, terutama fasilitas internet; sampai bagaimana memaksimalkan peranan stakeholder agar pembelajaran dapat berjalan dengan lebih baik dan mendapatkan hasil yang maksimal.

Kegiatan Pengabdian kepada Masyarakat ini berjalan selama 3 hari, dikarenakan kami memberikan kegiatan pelatihan dan pembimbingan lanjutan dalam pemanfaatan web enhanced course bagi para peserta. Melalui pelatihan lanjutan ini para peserta dapat lebih berkonsultasi mengenai kesulitan yang masih mereka hadapi, salah satunya dalam proses pembuatan Google Form. Selain masalah teknis tersebut, terdapat kendala lainnya yang lebih besar yakni fasilitas internet di SDN Gili Timur dan tempat tinggal siswa khususnya dan di Kabupaten Bangkalan pada umumnya yang masih kurang baik. Hal tersebut dikarenakan jaringan listrik yang tersedia di Kabupaten Bangkalan tidak maksimal, listrik sering mati terutama jika musim penghujan. Otomatis dapat langsung memutuskan jaringan internet. Hal ini tentunya dapat menjadi faktor penghambat berlangsungnya pembelajaran daring. Menurut (Rusman, 2010), hal-hal yang dapat difasilitasi internet antara lain: 1) discovery (penemuan); 2) communication (komunikasi); 3) collaboration (kolaborasi).

Melalui kerjasama yang dilaksanakan oleh guru, sekolah, orang tua, dan siswa, diharapkan nantinya dapat menciptakan pembelajaran daring yang lebih baik dan menyenangkan, serta tujuan pembelajaran yang diinginkan dapat tercapai. Pembelajaran kolaboratif berbasis online dapat dijadikan sebagai solusi bagi siswa di masa pandemi Covid-19, dan ditengah tuntutan kemajuan teknologi informasi dan komunikasi. Pembelajaran kolaboratif (collaborative learning) yang didukung dengan teknologi berpengaruh pada peningkatan interaksi dan kerjasama antar siswa. Hal ini didukung oleh hasil penelitian Hoyles, Healy \& Pozzi (1994) dalam (Hamidy, A \& Purboningsih, 2016) yang menjelaskan bahwa terdapat interaksi yang cukup kuat antara keterlibatan siswa dalam pembelajaran kolaboratif berbasis teknologi dengan kemampuan berpikir tingkat tinggi, membentuk hipotesis dan merefleksi siswa.

\section{SIMPULAN}

Berdasarkan pengamatan hasil kegiatan Pengabdian kepada Masyarakat, dapat disimpulkan bahwa setelah dilaksanakan pelatihan minat para guru dan karyawan SDN Gili Timur 2 Bangkalan meningkat untuk dapat memanfaatkan web enhanced course dan collaborative learning sebagai penunjang pembelajaran di SDN Gili 
921 Pelatihan Pemanfaatan Web Enhanced Course dan Collaborative Learning sebagai Penunjang Pembelajaran -Yudha Popiyanto, Savitri Suryandari, Anna Roosyanti

DOI: https://doi.org/10.31004/abdidas.v2i4.387

Timur 2 Bangkalan. Motivasi guru dan karyawan dalam melaksanakan pembelajaran daring semakin meningkat setelah dilaksanakan sharing mengenai kendala-kendala yang dihadapi oleh guru, sekolah, siswa, dan orang tua selama pembelajaran daring.

\section{UCAPAN TERIMA KASIH}

Dalam kesempatan ini kami mengucapkan terima kasih yang sebesar-besarnya kepada:

1. Ketua Lembaga Penelitian dan Pengabdian kepada Masyarakat Universitas Wijaya Kusuma Surabaya, yang telah memberikan fasilitas dalam pelaksanaan kegiatan Pengabdian kepada Masyarakat.

2. Dekan Fakultas Bahasa dan Sains Universitas Wijaya Kusuma Surabaya, yang telah memberikan kemudahan dalam pelaksanaan kegiatan Pengabdian kepada Masyarakat.

3. Ketua Program Studi PGSD Universitas Wijaya Kusuma Surabaya, yang telah memberikan dukungan dalam pelaksanaan kegiatan Pengabdian kepada Masyarakat.

4. Para Dosen Program Studi PGSD Universitas Wijaya Kusuma Surabaya, yang telah memberikan dukungan selama pelaksanaan kegiatan Pengabdian kepada Masyarakat.

5. Kepala Sekolah, Guru, dan karyawan SDN Gili Timur 2 Bangkalan, yang telah banyak membantu dan berpartisipasi aktif selama pelaksanaan kegiatan Pengabdian kepada Masyarakat.

\section{DAFTAR PUSTAKA}

Asyhari, A., \& Diani, R. (2017). Pembelajaran fisika berbasis web enhanced course: mengembangkan web-logs pembelajaran fisika dasar I. Jurnal Inovasi Teknologi Pendidikan, 4((1)), 13-25.

Basuki, H.O, D. (2021). Pendidikan Kesehatan tentang Rumah Sehat Covid-19 Bagi Kader Covid-19 di Desa Bogorejo Merakurak Tuban Tahun 2021. ABDIMASNU: Jurnal Pengabdian Kepada Masyarakat, 1(1), 2126.

Hamidy, A \& Purboningsih, D. (2016). Pembelajaran Kolaboratif Berbasis Online dalam Perkuliahan Filsafat Pendidikan Matematika. PRISMA. PRISMA, Prosiding Seminar Nasional Matematika:, 138-144.

Rusman. (2010). Model-Model Pembelajaran: Mengembangkan Profesionalisme Guru. Rajawali Press.

Sa`ud, U. S. (2010). Inovasi Pendidikan. Bandung. Alfabeta.

WHO. (2020). Coronavirus Disease 2019 (COVID-19) World Health Situation Report 1 WHO Indonesia Situation Report, 2019 (March), 8. 